\title{
A336C/A336T/T337C variations in HBV core gene and spontaneous hepatitis $B$ e antigen loss in chronic hepatitis B patients
}

\author{
Wen Fan ${ }^{1,2}$, Lu Huang ${ }^{1}$, Zhiming zhou ${ }^{1}$ and Yirong Li $\mathrm{Li}^{1,3^{*}}$
}

\begin{abstract}
Background: A336C/A336T/T337C variations in HBV core gene were demonstrated to relate to the decreases in serum HBV DNA levels and HBV replication in chronic hepatitis B patients. Usually the drastic decrease in serum HBV DNA levels correlates with spontaneous HBeAg loss during the course of chronic HBV infection. The aim of the present study was to investigate whether there was correlation between A336C/A336T/T337C variations and spontaneous HBeAg loss

Methodology/Principal Findings: A modified PCR-RFLP assay and ELISA were adopted to determine A336C/ A336T/T337C variations and serum HBeAg levels in chronic hepatitis B patients without any antiviral therapy, respectively, whereas G1896A variation and HBV genotype were detected using Taqman-PCR assay. RFLP pattern C, E, G, C/G mixture and a new pattern $C^{\prime}$ were found in this study. A336C/A336T/T337C variations occurred in 40/166 (24.1\%) chronic hepatitis B patients. Chi-square test showed that C336/T336/C337 variants was more frequent in chronic hepatitis B patients with A1896 variants than those with the wild type G1896 ( $\chi 2=4.7, P=0.03)$, and moreover, patients with C336/T336/C337 variants had a significantly lower HBeAg-positive percentage than those with the wild type $A 336 / T 337$. Binary logistic regression identified genotype $B(O R=4.1,95 \% C l=1.8-9.2, P=$ $0.001)$, the presence of $\mathrm{C} 336 / \mathrm{T} 336 / \mathrm{C} 337$ variants $(\mathrm{OR}=3.2,95 \% \mathrm{Cl}=1.2-8.5, \mathrm{P}=0.02)$ and $\mathrm{A} 1896$ variants $(\mathrm{OR}=7.8$, $95 \% \mathrm{Cl}=3.3-18.5, \mathrm{P}<0.001)$ as independent factors associated with spontaneous HBeAg loss.
\end{abstract}

Conclusion/Significance: A336C/A336T/T337C were naturally occurring polymorphisms in HBV core gene, and moreover, the presence of C336/T336/C337 variants was first demonstrated to be an independent factor associating with spontaneous HBeAg loss in chronic hepatitis B patients.

\section{Background}

Infection with the hepatitis B virus (HBV) remains a very important human disease, with an estimated 400 million people infected chronically worldwide. It is reported that about 1.5 million people die annually as a result of infection, most of them in Asia and Africa. In China, chronic HBV infection is also a major public health problem and associated with a wide range of clinical states, from an asymptomatic carrier state with a normal liver function to severe liver disease, which includes liver cirrhosis and hepatocellular carcinoma $[1,2]$.

\footnotetext{
*Correspondence: liyirong838@163.com

'Laboratory Department, Union Hospital, Tongji Medical College, Huazhong

University of Science and Technology, Wuhan, China 430022

Full list of author information is available at the end of the article
}

Spontaneous hepatitis B e antigen ( $\mathrm{HBeAg}$ ) loss during the course of chronic HBV infection is usually accompanied by the disappearance of the biochemical markers of hepatitis and a drastic decrease in viral replication. Factors associated with a higher rate of spontaneous HBeAg loss include certain HBV genotypes and certain HBV genetic diversities. Currently, HBV is classified into eight genotypes (A-H) based on an intergroup divergence of $8 \%$ or more in the complete nucleotide sequence of viral genomes. Genotypes B and C are prevalent in China. Previous cross-sectional and retrospective studies showed that genotype B patients had a significantly lower prevalence of $\mathrm{HBeAg}$ at presentation and a significantly higher rate of spontaneous $\mathrm{HBeAg}$ loss than genotype $\mathrm{C}$ [3-6]. In addition to genotype B, G1896A variation, not A1762T/ G1764A dual variations, is proposed to be another major
Ciomed Central

() 2011 Fan et al; licensee BioMed Central Ltd. This is an Open Access article distributed under the terms of the Creative Commons Attribution License (http://creativecommons.org/licenses/by/2.0), which permits unrestricted use, distribution, and reproduction in any medium, provided the original work is properly cited. 
mechanism to explain spontaneous $\mathrm{HBeAg}$ loss in the natural history of chronic HBV infection [7,8]. G1896A variation was mainly present in patients who were $\mathrm{HBeAg-}$ negative natives of Asian or Mediterranean basin, whereas A1762T/G1764A dual variations were detected in a similar proportion of $\mathrm{HBeAg-negative} \mathrm{and} \mathrm{HBeAg}$-positive patients [6,9-12].

A336C/A336T/T337C variations in HBV core gene, destroying the cleavage sites of Tsp509I, were demonstrated to correlate with the decreases in serum HBV DNA levels and HBV replication in chronic hepatitis $B$ patients, and moreover, A336C/A336T variations caused the substitution of Glu-83 with Asp in HBcAg [13]. $\mathrm{HBeAg}$ is transcribed from the precore/core gene like $\mathrm{HBcAg}$, therefore, A336C/A336T variations also cause the change of amino acid composition of HBeAg. Recent studies showed HBeAg up-regulation resulted in the decrease in TLR levels, which protected HBV from the immune response and led to higher HBV DNA viral load in HBeAg positive patients $[14,15]$. In addition, one multicenter study found that HBeAg titre correlated positively with serum HBV DNA and HBV replication [16]. Therefore, it was reasonable to suspect that A336C/A336T/T337C variations caused the decrease in serum HBV DNA levels by down-regulating $\mathrm{HBeAg}$ expression or promoting $\mathrm{HBeAg}$ loss. In order to investigate whether there was correlation between A336C/A336T/T337C variations and spontaneous $\mathrm{HBeAg}$ loss, the cumulative rates of spontaneous HBeAg loss between patients with C336/T336/C337 variants and the wild type A336/T337 were compared by analyzing a cohort of 166 Chinese chronic hepatitis B patients without any antiviral therapy.

\section{Methods}

\section{Patients, samples and the extraction of HBV DNA}

This is a cross-sectional study using stored serum samples from 166 chronic hepatitis B patients with genotype $\mathrm{B}$ and genotype $\mathrm{C}$ in Union Hospital of Huazhong University of Science and Technology in 2009. Chronic HBV infection was defined as persistent positivity for hepatitis B surface antigen (HBsAg) for at least six months at presentation. Patients with malignancy, liver cirrhosis, antiHCV positivity, anti-HIV positivity and autoimmune disease were excluded. Before collecting blood samples, all patients had never been treated with any antiviral therapy. Informed consent was obtained from all of the patients. The study was approved by the Ethics Committee of Union Hospital, Tongji Medical College, Huazhong University of Science and Technology. Serum samples were stored at $-80^{\circ} \mathrm{C}$ before they were tested. HBV DNA was extracted from $100 \mu \mathrm{l}$ of serum with extraction solution in a PCR-fluorescence quantification kit for HBV (Kelong, Shanghai, China) by the protocol described by the manufacturer.

\section{Serology}

HBsAg, HBeAg, anti-HBs antibodies, anti-HBc antibodies, anti-HBe antibodies, anti-HCV and anti-HIV antibodies were determined with commercial assay kits (InTec, Xiamen, China).

\section{Real-time quantification of serum HBV-DNA}

Quantification of serum HBV-DNA was carried out by real-time PCR assay using the method described before [13]. HBV-DNA levels were expressed as log copies/ml.

\section{HBV core gene specific PCR-RFLP (polymerase chain} reaction-restriction fragment length polymorphism) assay and HBV core gene sequencing

The presence of HBV core gene A336C/A336T/T337C variations in patient's sera were determined by a modified PCR-RFLP assay and cleaved PCR products were electrophoresed on $2.5 \%$ agarose gel $[13,17]$, and five PCR amplicons per RFLP pattern were sequenced directly to confirm the accuracy of PCR-RFLP assay. The restriction enzyme Tsp509I and primers for amplification and sequencing were in agreement with those used in reference [13].

\section{Detection of G1896A variation in HBV core gene}

G1896A variation in HBV core gene was detected with PCR-fluorescence detection kit based on Taqman MGB (minor groove binder) probes (Biocore, Hangzhou, China). The amplification and detection were carried out using the LightCycler ${ }^{\circledR}$ Systems for real-time PCR (Roche Diagnostic, Switzerland). For each sample, real-time PCR reaction $\mathrm{A}$ and $\mathrm{B}$ were performed in two different capillary tubes according to the instructions of the manufacturer. In brief, the real-time PCR reaction was carried out in a final volume of $20.4 \mu \mathrm{l}$, consisting of $18.4 \mu \mathrm{l}$ of master reaction mixture $\mathrm{A}$ or $\mathrm{B}$ and $2 \mu \mathrm{l}$ of DNA template. Thermal cycling conditions were as follows: One cycle of $37^{\circ} \mathrm{C}$ for two minutes and $94^{\circ} \mathrm{C}$ for two minutes, followed by 35 cycles of $93^{\circ} \mathrm{C}$ for five seconds and $62^{\circ} \mathrm{C}$ for 30 seconds at a programmed temperature transition rate of $20^{\circ} \mathrm{C} / \mathrm{s}$, then cooled at $40^{\circ} \mathrm{C}$ for less than one second. Monitoring of fluorescence intensity occurred at regular intervals during the annealing-extension phase. The recombinant plasmids including wild type G1896(or A1896 mutant) were used as negative control(or positive control). Ct value obtained from real-time PCR was adopted to identify wild type G1896 and A1896 mutant and the identification standards were list in Table 1.

\section{HBV genotyping}

HBV was genotyped with PCR-fluorescence diagnosis kit based on Taqman probes (Kelong, Shanghai, China). The amplification and detection were carried out with the MXP3000 ${ }^{\circledR}$ real-time thermocycler (Stratagene, La 
Table 1 The standards for identifying HBV genotypes, G1896 and A1896

\begin{tabular}{ll}
\hline & Identification standards \\
\hline A1896 & $\mathrm{Ct}(\mathrm{A}) \leq 38$ and $\mathrm{Ct}(\mathrm{B}) \geq 40$ \\
Genotype B & $\mathrm{Ct}(\mathrm{A}) \leq 38$ and $\mathrm{Ct}(\mathrm{B}) \leq 38$ \\
Genotype $\mathrm{C}$ & $\mathrm{Ct}(\mathrm{FAM}) \leq 36$ and $\mathrm{Ct}(\mathrm{Hex}) \geq 40$ \\
Genotype B/C mixture & $\mathrm{Ct}(\mathrm{FAM}) \geq 40$ and $\mathrm{Ct}(\mathrm{Hex}) \leq 36$ \\
Uncertain Genotype & $\mathrm{Ct}(\mathrm{FAM}) \leq 36$ and $\mathrm{Ct}(\mathrm{Hex}) \leq 36$ \\
\hline
\end{tabular}

Jolla, CA, USA). Real-time PCR reaction was performed in eppendorf tube according to the instruction provided by the manufacturer. In brief, the real-time PCR reaction was carried out in a final volume of $30 \mu \mathrm{l}$, consisting of $26 \mu \mathrm{l}$ of master reaction mixture and $4 \mu \mathrm{l}$ of DNA template. Real time PCR program consisted of heating at $50^{\circ} \mathrm{C}$ for 2 minutes and $94^{\circ} \mathrm{C}$ for 5 minutes, followed by 40 cycles of a two stage temperature profile of $93^{\circ} \mathrm{C}$ for 15 seconds and $60^{\circ} \mathrm{C}$ for 45 seconds at a programmed temperature transition rate of $3^{\circ} \mathrm{C} / \mathrm{s}$. Fluorescence emitted from reporter dyes FAM and $\mathrm{Hex}^{\mathrm{TM}}$ was monitored at regular intervals during the annealingextension phase respectively. Ct value obtained from real-time PCR was adopted to identify HBV genotypes and the identification standards were list in Table 1.

\section{Statistical analysis}

Statistical analysis was carried out with the SPSS 15.0 software package. Chi-square test was used for comparison of categorical data. Binary logistic regression analysis was adopted to estimate the independent factors associating with spontaneous HBeAg loss. During statistical analysis, serum ALT(alanine aminotransferase) levels, serum HBV DNA levels and age were transformed into categorical variables, respectively: (1) serum ALT levels were categorized into normal group $(\leq 50 \mathrm{U} / \mathrm{L})$ and abnormal group ( $>50 \mathrm{U} / \mathrm{L})$; (2) serum HBV DNA levels were categorized into mild elevated group $(<6.0)$ and severely elevated group $(\geqq 6.0$ ); (iii)age were grouped into $<35$ years and $\geqq 35$ years. The results were presented as odds ratios (OR), 95\% confidence intervals (CI), wald values and $\mathrm{P}$ values. $\mathrm{P} \leq 0.05$ was considered statistically significant.

\section{Results}

RFLP patterns and A336C/A336T/T337C variations in chronic hepatitis $B$ patients

A336C/A336T/T337C variations in HBV core gene were determined with a modified PCR-RFLP assay on total 166 serum samples collected from chronic hepatitis B patients. Five RFLP patterns cleaved by restriction enzyme Tsp509I, namely RFLP C, C', E, G and C/G mixture were found. RFLP C' was a new pattern found in this study(see Figure 1). RFLP C, C, E, G and C/G mixture occurred in 101(60.8\%),1(0.006\%) 24(14.5\%),27 (16.3\%),13(7.8\%) samples, respectively. Sequencing of HBV core gene demonstrated complete match between RFLP patterns and SNPs (single nucleotide polymorphisms) A336C/A336T/T337C (data not shown). Sequencing also showed that $\mathrm{A} 336 \mathrm{C} / \mathrm{A} 336 \mathrm{~T} / \mathrm{T} 337 \mathrm{C}$ variations occurred in serum samples presenting with RFLP patterns $\mathrm{G}$ and $\mathrm{C} / \mathrm{G}$ mixture (A336C/A336T/T337C variations were found in part of HBV DNA from serum samples with RFLP patterns C/G mixture, therefore, serum samples showing RFLP C/G mixture were also considered to be presence of C336/T336/C337 variants). A336C/A336T/T337C variations occurred in 40/166 (24.1\%) chronic hepatitis B patients without any antiviral therapy (See Table 2).

\section{A336C/A336T/T337C variations correlated with G1896A variation and the decrease in serum HBV DNA levels} G1896A was the most common variation in precore gene and occurred in 75/166(45.2\%) chronic hepatitis B patients in this study. C336/T336/C337 variants were found in 24/75 (32.0\%) chronic hepatitis B patients with A1896 variants and 16/91(17.6\%) chronic hepatitis B patients with the wild type G1896. Chi-square test showed C336/T336/C337 variants were more frequent in chronic hepatitis B patients with A1896 variants than those with the wild type $\mathrm{G1896}(\chi 2=4.7, \mathrm{P}=0.03)$, suggesting that $\mathrm{A} 336 \mathrm{C} / \mathrm{A} 336 \mathrm{~T} / \mathrm{T} 337 \mathrm{C}$ variations correlated closely with G1896A variation (See Table 2). In addition, patients with C336/T336/C337 variants had a significant lower rate of severely elevated serum HBV DNA levels than those with the wild type A336/T337 $(\chi 2=6.6, \mathrm{P}=0.01)$.

HBV genotype was determined on total of 166 chronic hepatitis B patient with Taqman-PCR assay. Of the 166 patients, 87 (52.4\%) were infected with HBV genotype B and the remaining 79 (47.6\%) were infected with genotype C. A336C/A336T/T337C variations occurred in 26/ 87 (29.9\%) chronic hepatitis B patients with genotype B and 14/79 (17.7\%) patients with genotype C, and Chisquare test showed that there was no significant difference in the rate of $\mathrm{A} 336 \mathrm{C} / \mathrm{A} 336 \mathrm{~T} / \mathrm{T} 337 \mathrm{C}$ variations between HBV genotype $\mathrm{B}$ and $\mathrm{C}(\chi 2=3.3, \mathrm{P}=0.07$, See Table 2).

The presence of C336/T336/C337 variants was an independent factor associating with spontaneous $\mathrm{HBeAg}$ loss in chronic Hepatitis B patients

In this study, HBeAg was found in 77/166(46.4\%) chronic hepatitis B patients. Chi-square test showed chronic hepatitis B patients with C336/T336/C337 variants had a significantly lower HBeAg-positive percentage than those with the wild type A336/T337(22.5\% vs $54.0 \%, \chi 2=12.1, \mathrm{P}=0.001)$, indicating that the 


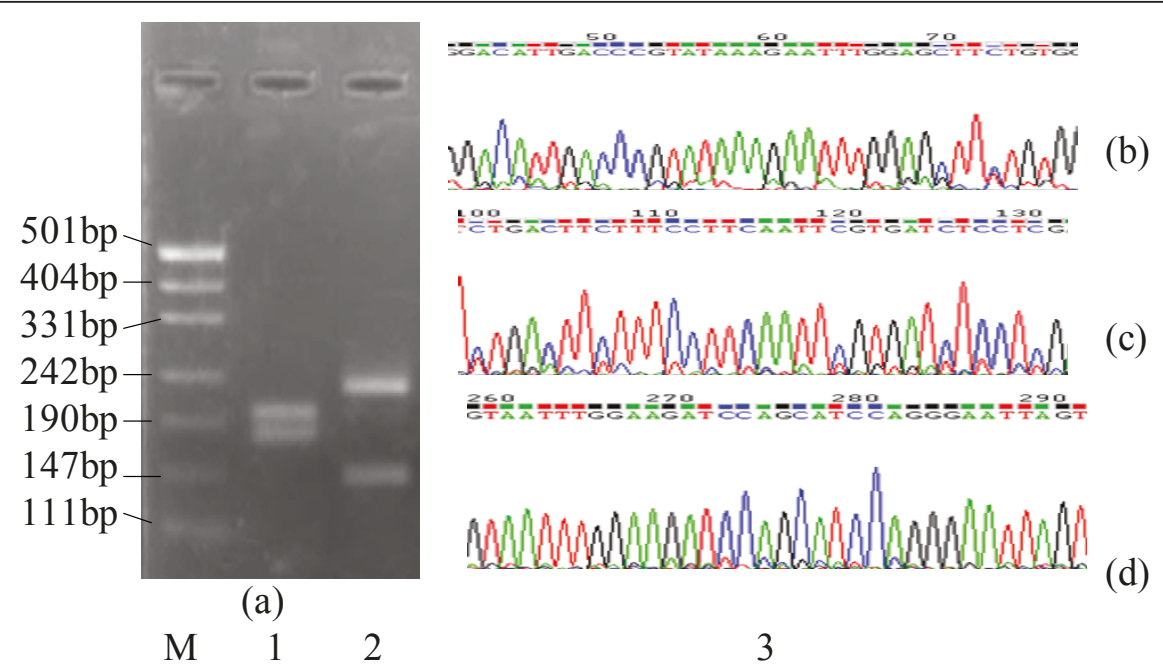

Figure 1 HBV core gene RFLP pattern C'(M. DNA marker;1. RFLP E;2. RFLP C' 3. Cleavage site of Tsp509/ were found at position 61 (b),116 (c),261 and 286(d) corresponding to nucleotide 110,165,310 and 335 in HBV core gene showing RFLP C', respectively).

presence of C336/T336/C337 variants was closely associated with spontaneous HBeAg loss in chronic hepatitis B patients (See Table 3). Furthermore, Chi-square test also showed that the presence of A1896 variant, age $\geqq 35$ years, HBV genotype B and serum HBV DNA levels $<6.0$ were also related closely to spontaneous $\mathrm{HBeAg}$ loss in chronic hepatitis B patients (See Table 3),

Table 2 Comparison of important characteristics between 166 patients with the wild type A336/T337 and A336C/ A336T/T337C variants

\begin{tabular}{|c|c|c|c|c|}
\hline & $\begin{array}{c}\text { A336/T337 } \\
(n=126)\end{array}$ & $\begin{array}{c}\text { C336/T336/C337 } \\
(n=40)\end{array}$ & $\chi^{2}$ & $p$ value \\
\hline $\mathrm{HBeAg}$ & & & 12.1 & 0.001 \\
\hline Positive & 68 & 9 & & \\
\hline Negative & 58 & 31 & & \\
\hline G1896 variation & & & 4.7 & 0.03 \\
\hline G1896 & 75 & 16 & & \\
\hline A1896 & 51 & 24 & & \\
\hline HBV genotype & & & 3.4 & 0.07 \\
\hline $\mathrm{B}$ & 61 & 26 & & \\
\hline C & 65 & 14 & & \\
\hline \multicolumn{5}{|c|}{ serum HBV DNA levels } \\
\hline$<6$ & 69 & 31 & 6.6 & 0.01 \\
\hline$\geq 6$ & 57 & 9 & & \\
\hline \multicolumn{5}{|l|}{ Age } \\
\hline$<35$ & 62 & 18 & 0.2 & 0.64 \\
\hline$\geq 35$ & 64 & 22 & & \\
\hline Sex & & & 2.4 & 0.12 \\
\hline Male & 100 & 27 & & \\
\hline Female & 26 & 13 & & \\
\hline Serum ALT levels & & & 0.1 & 0.74 \\
\hline$\leq 50 \mathrm{U} / \mathrm{L}$ & 75 & 25 & & \\
\hline$>50 \mathrm{U} / \mathrm{L}$ & 51 & 15 & & \\
\hline
\end{tabular}

therefore, A336C/A336T/T337C variations, serum HBV DNA levels, G1896A variation, age and HBV genotype were entered into a binary logistic regression model to determine which was the independent factor associating with spontaneous $\mathrm{HBeAg}$ loss. The results of the analysis were displayed in Table 4. Although the presence of

Table 3 Comparison of important characteristics between 166 patients with positive $\mathrm{HBeAg}$ and negative $\mathrm{HBeAg}$

\begin{tabular}{|c|c|c|c|c|}
\hline & $\begin{array}{c}\text { HBeAg } \\
\text { positive } \\
(n=77)\end{array}$ & $\begin{array}{c}\mathrm{HBeAg} \\
\text { negative } \\
(\mathrm{n}=89)\end{array}$ & $\chi^{2}$ & $\begin{array}{c}P \\
\text { value }\end{array}$ \\
\hline $\begin{array}{c}\text { A336C/A336T/T337C } \\
\text { variations }\end{array}$ & & & 12.1 & 0.001 \\
\hline A336/Т337 & 68 & 58 & & \\
\hline C336/T336/C337 & 9 & 31 & & \\
\hline G1896 variation & & & 42.3 & $<0.001$ \\
\hline G1896 & 63 & 28 & & \\
\hline A1896 & 14 & 61 & & \\
\hline HBV genotype & & & 14.8 & $<0.001$ \\
\hline $\mathrm{B}$ & 28 & 59 & & \\
\hline C & 49 & 30 & & \\
\hline serum HBV DNA levels & & & 23.9 & $<0.001$ \\
\hline$<6$ & 31 & 69 & & \\
\hline$\geq 6$ & 46 & 20 & & \\
\hline Age & & & 4.6 & 0.03 \\
\hline$<35$ & 44 & 36 & & \\
\hline$\geq 35$ & 33 & 53 & & \\
\hline Sex & & & 0.001 & 0.94 \\
\hline Male & 59 & 68 & & \\
\hline Female & 18 & 21 & & \\
\hline Serum ALT levels & & & 3.2 & 0.07 \\
\hline$\leq 50 \mathrm{U} / \mathrm{L}$ & 52 & 48 & & \\
\hline$>50 \mathrm{U} / \mathrm{L}$ & 25 & 41 & & \\
\hline
\end{tabular}


Table 4 Binary logistic regression analysis of potential factors associating with spontaneous $\mathrm{HBeAg}$ loss

\begin{tabular}{|c|c|c|c|c|}
\hline Factors & $\begin{array}{l}\text { Odds } \\
\text { Ration }\end{array}$ & $95 \% \mathrm{Cl}$ & $\begin{array}{l}\text { Wald } \\
\text { value }\end{array}$ & $\begin{array}{c}P \\
\text { value }\end{array}$ \\
\hline \multicolumn{5}{|c|}{$\begin{array}{c}\text { A336C/A336T/T337C } \\
\text { variations }\end{array}$} \\
\hline A336/T337 & 1 & & & \\
\hline C336/T336/C337 & 3.2 & $1.2-8.5$ & 5.2 & 0.02 \\
\hline \multicolumn{5}{|l|}{ G1896 variation } \\
\hline G1896 & 1 & & & \\
\hline A1896 & 7.8 & $\begin{array}{l}3.3- \\
18.5\end{array}$ & 21.4 & $<0.001$ \\
\hline \multicolumn{5}{|l|}{ HBV genotype } \\
\hline B & 4.1 & $1.8-9.2$ & 11.8 & 0.001 \\
\hline C & 1 & & & \\
\hline \multicolumn{5}{|c|}{ serum HBV DNA levels } \\
\hline$<6$ & 1 & & & \\
\hline$\geqq 6$ & 0.5 & $0.2-1.1$ & 3.3 & 0.07 \\
\hline \multicolumn{5}{|l|}{ Age } \\
\hline$<35$ & 1 & & & \\
\hline$\geqq 35$ & 1.9 & $0.8-4.1$ & 2.4 & 0.12 \\
\hline
\end{tabular}

A1896 variant $(\mathrm{OR}=7.8,95 \% \mathrm{CI}=3.3-18.5, \mathrm{P}<0.001)$ and $\mathrm{HBV}$ genotype $\mathrm{B}(\mathrm{OR}=4.1,95 \% \mathrm{CI}=1.8-9.2, \mathrm{P}=$ 0.001 ) were the most two importantly independent factors associating with spontaneous $\mathrm{HBeAg}$ loss, the presence of C336/T336/C337 variants was also an independent factor associating with spontaneous $\mathrm{HBeAg}$ $\operatorname{loss}(\mathrm{OR}=3.2,95 \% \mathrm{CI}=1.2-8.5, \mathrm{P}=0.02)($ See Table 4$)$.

\section{Discussion}

Recent studies have identified several HBV variants and mutants playing an important role in disease pathogenesis, immune escape, and resistance to antiviral therapy $[18,19]$. HBV variants such as A1896 occur under the selective pressures from the host's immune system and from viral factors $[20,21]$, whereas HBV mutants, such as rtI204 and rtV204, usually occur secondary to exogenous factors such as lamivudine and associate with a specific phenotype [12,22]. In this cross-sectional study, 166 serum samples from chronic hepatitis B patients without any antiviral therapy were enrolled, and A336C/A336T/ $\mathrm{T} 337 \mathrm{C}$ variations and $\mathrm{G} 1896 \mathrm{~A}$ variation occurred in $24.1 \%(40 / 166)$ and $45.2 \%(75 / 166)$ serum samples, respectively. Statistical analysis showed A336C/A336T/ T337C variations were closely associated with G1896A variation and more prone to occur in samples with A1896 variants, therefore, A336C/A336T/T337C were naturally occurring polymorphisms as well as G1896A. In addition, chronic hepatitis B patients with C336/T336/ C337 variants had a significant lower rate of severely elevated serum HBV DNA levels than those with the wild type A336/T337, which was in agreement with previous report that $\mathrm{A} 336 \mathrm{C} / \mathrm{A} 336 \mathrm{~T} / \mathrm{T} 337 \mathrm{C}$ variations caused the decreases in serum HBV DNA levels and HBV replication [13].

The natural history of chronic HBV infection can be divided into four phases: immune tolerance, HBeAg-positive chronic hepatitis, inactive $\mathrm{HBsAg}$ carrier and $\mathrm{HBeAg}$ negative chronic hepatitis [23]. The common features of immune tolerance phase and $\mathrm{HBeAg}$-positive chronic hepatitis phase are positive for HBeAg and high levels of serum HBV DNA, whereas inactive HBsAg carrier phase is characterized by the absence of $\mathrm{HBeAg}$ and decrease in HBV DNA. Therefore, spontaneous HBeAg loss during the course of chronic HBV infection usually correlates with a drastic decrease in serum HBV DNA and disappearance of biochemical markers of hepatitis [23-27]. In this study, the rate of severely elevated serum HBV DNA levels in HBeAg-positive patients was higher than that in $\mathrm{HBeAg}$-negative patients, supporting that $\mathrm{HBeAg}$ expression was strongly related to HBV replication and high serum HBV DNA levels. However, binary regression analysis showed that serum HBV DNA levels $<6.0$ was not an independent factor associating with spontaneous $\mathrm{HBeAg}$ loss. One retrospective and follow-up study carried out in Taiwan showed that rates of spontaneous HBeAg loss were not statistically different between patients with low and high baseline serum HBV DNA levels and baseline serum HBV DNA levels were not independent factors for predicting HBeAg loss [5]. Taken together, these findings did not support that serum HBV DNA levels were independent factors associating with spontaneous HBeAg loss in chronic hepatitis B.

$\mathrm{HBeAg}$ loss can occur spontaneously or secondary to treatment with nucleoside/nucleotide analogs and interferon. Spontaneous HBeAg loss, which occurs annually in as many as $10 \%$ to $20 \%$ of those with HBeAg-positive hepatitis, is an important landmark in the natural history of chronic HBV infection. In a population-based study of 1536 Alaskan natives who had HBV infection in adulthood, spontaneous loss was found in $70 \%$ during the 10-year follow-up period [28]. Factors associated with a higher rate of spontaneous $\mathrm{HBeAg}$ loss include the presence of A1896 variant and genotype B [5,23,29]. One cross-sectional study from China found that among 223 HBV DNA-positive chronic patients, the G1896A variation was found in $47 / 128 \mathrm{HBeAg}$-negative patients and 5/95 HBeAg-positive patients [3]. Similarly, in another multicenter study of 449 chronic hepatitis B patients with detectable HBV DNA, the A1896 variant was present in $7 \%$ of $\mathrm{HBeAg}$-positive and $36 \%$ of HBeAg-negative patients [11]. This study showed A1896 variant was present in 14/77 (18.2\%) HBeAg-positive patients and 61/89 (68.5\%) HBeAg-negative patients. Furthermore, binary regression analysis showed patients who presented with A1896 variant, as compared to having wild type G1896, were nearly 7.8 times more likely to occur spontaneous 
HBeAg loss $(\mathrm{OR}=7.8,95 \% \mathrm{CI}=3.3-18.5, \mathrm{P}<0.001)$, which supporting the presence of A1896 variants was one of the major mechanisms to explain spontaneous HBeAg loss in the natural history of chronic HBV infection.

In this study, genotypes $\mathrm{B}$ and $\mathrm{C}$ accounted for $52.4 \%$ $(87 / 166)$ and $47.6 \%(79 / 166)$ of chronic hepatitis B patients respectively. HBV genotype B was thought to be related to spontaneous $\mathrm{HBeAg}$ loss. One retrospective study of 146 Taiwanese adult HBeAg-positive hepatitis B carriers showed genotype C patients had a significantly lower rate of spontaneous HBeAg loss than genotype $B$ patients [5]. Another retrospective study of 332 Chinese patients with a mean follow-up of 48 months, genotype $B$ patients had a significantly lower prevalence of $\mathrm{HBeAg}$ at presentation and a significantly higher rate of spontaneous HBeAg loss during follow-up [3]. In agreement with the above two reports, chronic patients with genotype B were demonstrated to have a higher likelihood of spontaneous HBeAg loss than those with genotype $\mathrm{C}(\mathrm{OR}=4.1,95 \% \mathrm{CI}=1.8-9.2, \mathrm{P}=$ $0.001)$ in this study. It was more interesting to find that chronic hepatitis B patients with C336/T336/C337 variants had a significantly lower HBeAg-positive percentage than those with the wild type A336/T337, and moreover, logistic regression analysis showed the likelihood of HBeAg loss among chronic hepatitis B patients with C336/T336/C337 variants was nearly 3.2 times that of those with the wild type A336/T337 (OR = 3.2, 95\% $\mathrm{CI}=1.2-8.5, \mathrm{P}=0.02$ ), which demonstrated that the presence of C336/T336/C337 variants was an independent factor associating with spontaneous $\mathrm{HBeAg}$ loss. Therefore, A336C/A336T/T337C variations were proposed to be another major mechanism to explain spontaneous HBeAg loss in the natural history of chronic HBV infection as well as G1896A variation and genotype B $[7,8,30,31]$. Age was thought of as another factor influencing spontaneous HBeAg loss, but the real significance of age is now existence controversy. One longterm follow-up study in Alaska showed that older HBV carriers were more likely than younger carriers to clear HBeAg [28]. The other follow-up study in Taiwan showed age $\leq 35$ years was an independent factor associating with spontaneous $\mathrm{HBeAg}$ loss [5]. In this study chronic hepatitis B patients were grouped into age $<35$ years and age $\geqq 35$ years, and HBeAg-positive percentage were higher in group age $<35$ years than that in group age $\geqq 35$ years, but binary regression analysis in this study showed that age $\geqq 35$ years were not an independent factor associating with spontaneous $\mathrm{HBeAg}$ loss $(\mathrm{OR}=1.8,95 \% \mathrm{CI}=0.8-4.1, \mathrm{P}=0.12)$, which was not agreement with one of the above two studies. The possible reason was below: (i) cross-sectional study was used in this study, whereas retrospective and follow-up studies were adopted in the above two studies; (ii) age was a dynamic increasing variable.

In conclusion, A336C/A336T/T337C were naturally occurring polymorphisms in $\mathrm{HBV}$ core gene, and the presence of C336/T336/C337 variants was first demonstrated to be an independent factor associating with spontaneous HBeAg loss. This study also demonstrated that the presence of A1896 variant and HBV genotype B were also independent factors related to spontaneous HBeAg loss in chronic hepatitis B patients.

\section{Author details}

${ }^{1}$ Laboratory Department, Union Hospital, Tongji Medical College, Huazhong University of Science and Technology, Wuhan, China 430022. '2 Laboratory Department, Jingzhou First People's Hospital, Jingzhou, China 434000. ${ }^{3}$ Laboratory Department, West Area of Union Hospital, Tongji Medical College, Huazhong University of Science and Technology, Wuhan, China 430065 .

\section{Authors' contributions}

WF performed most of the experimental work. LH participated in specific PCR-RFLP assay. ZZ participated in the detection of G1896A variation in HBV core gene. $Y L$ was responsible for the planning of the study, data analysis, and drafted the manuscript. All authors have read and approved the final manuscript.

\section{Competing interests}

The authors declare that they have no competing interests.

Received: 6 November 2010 Accepted: 14 May 2011

Published: 14 May 2011

\section{References}

1. WM Lee, Hepatitis B virus infection. N Engl J Med. 337, 1733-45 (1997). doi:10.1056/NEJM199712113372406

2. YF Liaw, DI Tai, CM Chu, TJ Chen, The development of cirrhosis in patients with chronic type B hepatitis: a prospective study. Hepatology. 8, 493-6 (1988). doi:10.1002/hep.1840080310

3. CJ Chu, M Hussain, AS Lok, Hepatitis B virus genotype B is associated with earlier HBeAg seroconversion compared with hepatitis B virus genotype C. Gastroenterology. 122, 1756-62 (2002). doi:10.1053/gast.2002.33588

4. H Sumi, O Yokosuka, N Seki, M Arai, F Imazeki, T Kurihara., et al, Influence of hepatitis B virus genotypes on the progression of chronic type B liver disease. Hepatology. 37, 19-26 (2003). doi:10.1053/jhep.2003.50036

5. JH Kao, PJ Chen, MY Lai, DS Chen, Hepatitis B virus genotypes and spontaneous hepatitis B e antigen seroconversion in Taiwanese hepatitis B carriers. J Med Virol. 72, 363-9 (2004). doi:10.1002/jmv.10534

6. $\mathrm{CH}$ Chen, $\mathrm{CM}$ Lee, $\mathrm{CH}$ Hung, TH Hu, JH Wang, JC Wang., et al, Clinical significance and evolution of core promoter and precore mutations in HBeAg-positive patients with HBV genotype B and C: a longitudinal study. Liver Int. 27, 806-15 (2007). doi:10.1111/j.1478-3231.2007.01505.x

7. F Rodriguez-Frias, R Jardi, M Buti, M Schaper, E Hermosilla, A Valdes., et al, Hepatitis B virus genotypes and G1896A precore mutation in 486 Spanish patients with acute and chronic HBV infection. J Viral Hepat. 13, 343-50 (2006). doi:10.1111/j.1365-2893.2005.00691.x

8. S Tong, Impact of viral genotypes and naturally occurring mutations on biological properties of hepatitis B virus. Hepatol Res. 37(s1):3-8 (2007). doi:10.1111/j.1872-034X.2007.00097.x

9. MR Brunetto, MM Giarin, F Oliveri, E Chiaberge, M Baldi, A Alfarano., et al, Wild-type and e antigen-minus hepatitis B viruses and course of chronic hepatitis. Proc Natl Acad Sci USA. 88, 4186-90 (1991). doi:10.1073/ pnas.88.10.4186

10. H Okamoto, F Tsuda, Y Akahane, Y Sugai, M Yoshiba, K Moriyama., et al, Hepatitis B virus with mutations in the core promoter for an e antigen negative phenotype in carriers with antibody to e antigen. J Virol. 68, 8102-10 (1994) 
11. HL Chan, NW Leung, M Hussain, ML Wong, AS Lok, Hepatitis B e antigen negative chronic hepatitis B in Hong Kong. Hepatology. 31, 763-8 (2000). doi:10.1002/hep.510310330

12. CT Wai, RJ Fontana, Clinical significance of hepatitis B virus genotypes, variants, and mutants. Clin Liver Dis. 8, 321-52 (2004). doi:10.1016/j. cld.2004.02.006

13. $Y$ Li, X Wang, $F$ Chen, $R$ Ma, X Wen, $L$ Hu, Clinical significance of a set of single nucleotide polymorphisms of hepatitis B virus core gene in Chinese Han patients with chronic hepatitis B. J Med Virol. 80, 1885-90 (2008). doi:10.1002/jmv.21301

14. J Wu, M Lu, Z Meng, M Trippler, R Broering, A Szczeponek., et al, Toll-like receptor-mediated control of $\mathrm{HBV}$ replication by nonparenchymal liver cells in mice. Hepatology. 46, 1769-78 (2007). doi:10.1002/hep.21897

15. J Wu, Z Meng, M Jiang, R Pei, M Trippler, R Broering., et al, Hepatitis B virus suppresses toll-like receptor-mediated innate immune responses in murine parenchymal and nonparenchymal liver cells. Hepatology. 49, 1132-40 (2009). doi:10.1002/hep.22751

16. AJ Thompson, T Nguyen, D Iser, A Ayres, K Jackson, M Littlejohn., et al, Serum hepatitis B surface antigen and hepatitis B e antigen titers: disease phase influences correlation with viral load and intrahepatic hepatitis B virus markers. Hepatology. 51, 1933-44 (2010). doi:10.1002/hep.23571

17. NL Toan, LH Song, PG Kremsner, DN Duy, VQ Binh, B Koeberlein., et al, Impact of the hepatitis $B$ virus genotype and genotype mixtures on the course of liver disease in Vietnam. Hepatology. 43, 1375-84 (2006). doi:10.1002/hep.21188

18. K Hayashi, Y Katano, TX Chuong, Y Takeda, M Ishigami, A Itoh., et al, Prevalence of hepatitis B virus subgenotypes and basal core promoter, precore variants in patients with acute hepatitis B in central Vietnam. Intervirology. 52, 22-8 (2009). doi:10.1159/000210835

19. SG Selabe, E Song, RJ Burnett, MJ Mphahlele, Frequent detection of hepatitis B virus variants associated with lamivudine resistance in treated South African patients infected chronically with different HBV genotypes. J Med Virol. 81, 996-1001 (2009). doi:10.1002/jmv.21479

20. VE Buckwold, Z Xu, M Chen, TS Yen, JH Ou, Effects of a naturally occurring mutation in the hepatitis $B$ virus basal core promoter on precore gene expression and viral replication. J Virol. 70, 5845-51 (1996)

21. HL Chan, M Hussain, ASF Lok, Different hepatitis B virus genotypes are associated with different mutations in the core promoter and precore regions during hepatitis $B$ e antigen seroconversion. Hepatology. 29, 976-84 (1999). doi:10.1002/hep.510290352

22. LJ Stuyver, SA Locarnini, A Lok, DD Richman, WF Carman, JL Dienstag., et al, Nomenclature for anti-viral resistant human hepatitis B virus mutations in the polymerase region. Hepatology. 33, $751-7$ (2001). doi:10.1053/ jhep.2001.22166

23. S Pungpapong, WR Kim, JJ Poterucha, Natural history of hepatitis B virus infection: an update for clinicians. Mayo Clin Proc. 82, 967-75 (2007). doi:10.4065/82.8.967

24. M Bernardi, M Biselli, A Gramenzi, Chronic hepatitis B. Recent advances in diagnosis and treatment. Recenti Prog Med. 93, 397-402 (2002)

25. YF Liaw, N Leung, R Guan, GK Lau, I Merican, G McCaughan., et al, AsianPacific consensus statement on the management of chronic hepatitis $\mathrm{B}$ : a 2005 update. Liver Int. 25, 472-89 (2005). doi:10.1111/j.14783231.2005.01134.x

26. CH Chen, CM Lee, SN Lu, CS Changchien, JC Wang, JH Wang., et al, Comparison of sequence changes of precore and core promoter regions in $\mathrm{HBeAg}$-positive chronic hepatitis B patients with and without $\mathrm{HBeAg}$ clearance in lamivudine therapy. J Hepatol. 44, 76-82 (2006). doi:10.1016/j. jhep.2005.08.022

27. G Fattovich, F Bortolotti, F Donato, Natural history of chronic hepatitis B: special emphasis on disease progression and prognostic factors. $J$ Hepatol. 48, 335-52 (2008). doi:10.1016/j.jhep.2007.11.011

28. BJ McMahon, P Holck, L Bulkow, M Snowball, Serologic and clinical outcomes of 1536 Alaska Natives chronically infected with hepatitis B virus. Ann Intern Med. 135, 759-68 (2001)

29. K Hamasaki, K Nakata, Y Nagayama, A Ohtsuru, M Daikoku, K Taniguchi., et al, Changes in the prevalence of HBeAg-negative mutants hepatitis $B$ virus during the course of chronic hepatitis B. Hepatology. 20, 8-14 (1994). doi:10.1002/hep.1840200103

30. YH Huang, JC Wu, TT Chang, IJ Sheen, TI Huo, PC Lee., et al, Association of core promoter/precore mutations and viral load in e antigen-negative chronic hepatitis B patients. J Viral Hepat. 13, 336-42 (2006). doi:10.1111/ j.1365-2893.2005.00688.x

31. XM Peng, GM Huang, JG Li, YS Huang, YY Mei, ZL Gao, High level of hepatitis B virus DNA after HBeAg-to-anti-HBe seroconversion is related to coexistence of mutations in its precore and basal core promoter. World $J$ Gastroenterol. 28, 3131-34 (2005)

doi:10.1186/1743-422X-8-226

Cite this article as: Fan et al:: A336C/A336T/T337C variations in HBV core gene and spontaneous hepatitis $B$ e antigen loss in chronic hepatitis B patients. Virology Journal 2011 8:226.

\section{Submit your next manuscript to BioMed Central and take full advantage of:}

- Convenient online submission

- Thorough peer review

- No space constraints or color figure charges

- Immediate publication on acceptance

- Inclusion in PubMed, CAS, Scopus and Google Scholar

- Research which is freely available for redistribution 